\title{
BIM deletion polymorphisms in Hispanic patients with non-small cell lung cancer carriers of EGFR mutations
}

\author{
Andrés F. Cardona ${ }^{1,2,3, *}$, Leonardo Rojas ${ }^{4,5, *}$, Beatriz Wills ${ }^{2, *}$, Oscar Arrieta ${ }^{6, *}$, \\ Hernán Carranza ${ }^{1,2,3}$, Carlos Vargas ${ }^{1,2,3}$, Jorge Otero ${ }^{1,2,3}$, Luis Corrales-Rodriguez ${ }^{7}$, \\ Claudio Martín ${ }^{8}$, Noemí Reguart ${ }^{9}$, Pilar Archila ${ }^{2}$, July Rodríguez ${ }^{2}$, Mauricio Cuello ${ }^{10}$, \\ Carlos Ortíz ${ }^{1}$, Sandra Franco ${ }^{1}$, Christian Rolfo ${ }^{11}$, Rafael Rosell ${ }^{12}$, on behalf of the \\ CLICaP\# \\ ${ }^{1}$ Clinical and Traslational Oncology Group, Institute of Oncology, Clínica del Country, Bogotá, Colombia \\ ${ }^{2}$ Foundation for Clinical and Applied Cancer Research (FICMAC), Bogotá, Colombia \\ ${ }^{3}$ Clinical and Traslational Research Department, Faculty of Medicine, Universidad el Bosque, Bogotá, Colombia \\ ${ }^{4}$ Clinical Oncology Department, Centro Javeriano de Oncología, Hospital Universitario San Ignacio, Bogotá, Colombia \\ ${ }^{5}$ Faculty of Medicine, Pontificia Universidad Javeriana, Bogotá, Colombia \\ ${ }^{6}$ Thoracic Oncology Unit, Instituto Nacional de Cancerología (INCan), México City, México \\ ${ }^{7}$ Medical Oncology Department, Hospital San Juan de Dios, San José, Costa Rica \\ ${ }^{8}$ Thoracic Oncology Unit, Alexander Fleming Institute, Buenos Aires, Argentina \\ ${ }^{9}$ Medical Oncology Department, Hospital Clínic, Barcelona, Spain \\ ${ }^{10}$ Clinical Oncology Department, Hospital de Clínicas-UdeLAR, Montevideo, Uruguay \\ ${ }^{11}$ Early Clinical Trials Unit, Oncology Department, Antwerp University Hospital and Center for Oncological Research (CORE), \\ Antwerp University, Edegem, Belgium \\ ${ }^{12}$ Medical Oncology Department, Catalan Institute of Oncology, Hospital Germans Trias i Pujol, Badalona, Barcelona, Spain \\ \#Latin American Consortium for Lung Cancer Investigation \\ *These authors have contributed equally to this study \\ Correspondence to: Andrés F. Cardona, email: andres.cardona@clinicadelcountry.com, a_cardonaz@yahoo.com \\ Keywords: non-small cell lung cancer, BIM deletion, EGFR mutation, survival \\ Received: February 24, $2016 \quad$ Accepted: August 24, $2016 \quad$ Published: September 19, 2016
}

\section{ABSTRACT}

Background: Germline alterations in the proapoptotic protein Bcl-2-like 11 (BIM) can have a crucial role in diverse tumors. To determine the clinical utility of detecting BIM deletion polymorphisms (par4226 bp/ par363 bp) in EGFR positive non-smallcell lung cancer (NSCLC) we examined the outcomes of patients with and without BIM alterations.

Results: BIM deletion was present in 14 patients $(15.7 \%)$. There were no significant differences between patients with and without BIM-del in clinical characteristics or EGFR mutation type; however, those with BIM-del had a worse overall response rate (ORR) to erlotinib (42.9\% vs. $73.3 \%$ in patients without BIMdel; $\mathrm{p}=0.024$ ) as well as a significantly shorter progression-free survival (PFS) (10.8 BIM-del+ vs. 21.7 months for patients without BIM-del; $\mathrm{p}=0.029$ ) and overall survival (OS) (15.5 BIM-del+ vs. 34.0 months for patients without BIM-del; $\mathrm{p}=\mathbf{0 . 0 3 5}$ ). Multivariate Cox regression analysis showed that BIM-del+ was an independent indicator of shorter PFS (HR 3.0; 95\%CI 1.2-7.6; $p=0.01$ ) and OS (HR 3.4; 95\%CI 1.4-8.3; $p=0.006$ ).

Methods: We studied 89 NSCLC Hispanic patients with EGFR mutation who were treated with erlotinib between January 2009 and November 2014. BIM deletion polymorphisms (BIM-del) was analyzed by PCR in formalin-fixed paraffin-embedded 
(FFPE) tissues of tumor biopsies. We retrospectively analyzed clinical characteristics, response rate, toxicity, and outcomes among patients with and without BIM-del.

Conclusions: The incidence of BIM-del found in Hispanic patients is similar to that previously described in Asia. This alteration is associated with a poor clinical response to erlotinib and represents an independent prognostic factor for patients who had NSCLC with an EGFR mutation.

\section{INTRODUCTION}

Lung cancer is the leading cause of cancer related death in the developed countries and in Latin America, and non-small-cell lung cancer (NSCLC) accounts for most cases $[1,2]$. Activating mutations in the epidermal growth factor receptor $(E G F R)$ as a therapeutic target for NSCLC has changed the course of the disease [3]. The frequency of EGFR mutations vary according to the population; in Caucasians EGFR mutations occurs in 10 to $15 \%$, whereas in East Asia and Latin America these are more frequent occurring in 30 to $50 \%$ of lung adenocarcinoma patients [4-6]. EGFR tyrosine kinase inhibitors (TKIs), such as gefitinib, erlotinib, and afatinib, are widely used to treat advanced NSCLC harboring an EGFR mutation. Such drugs have improved the progression free survival (PFS), overall survival (OS) and quality of life compared with first line platinum-based doublet chemotherapy [7-10]. However, drug resistance invariably emerged and most patients develop recurrence within 10 to 16 months after initial EGFR-TKI treatment (acquired resistance) [11]. Several mechanisms of secondary resistance have been revealed, including: EGFR T790M mutation (the most frequent), mesenchymalepithelial transition, $M E T$ amplification, phosphatidylinositol4-5-bisphosphate 3-kinase mutations (PI3K) and small-cell lung cancer transformation [12-15]. Nevertheless, around $30 \%$ of patients with EGFR-activating mutations do not show objective response (OR) to EGFR TKIs (primary resistance) $[7,8]$. The mechanisms and characteristics of primary resistance are less known and none of these explain the majority of cases. Some of mechanisms of primary resistance include: v-Ki-ras2 Kirsten rat sarcoma viral oncogene homolog $(K R A S)$ mutations, de novo MET amplification, and phosphatase and tensin-homolog (PTEN) loss [16-19]. An interesting mechanism related with germline polymorphisms is proapoptotic protein Bcl-2-like 11 (BIM) which has been described and could potentially explain primary resistance to EGFR TKIs [20].

BIM is a member of the B-cell CLL/Lymphoma 2 (Bcl-2) family of proteins and has been related with apoptosis modulation triggered by EGFR-TKIs [2123]. BIM deletion polymorphisms (BIM-del) consist of intronic deletion polymorphisms in the gene. These polymorphisms switched BIM splicing from exon 4 to exon 3, which resulted in expression of BIM isoforms lacking the proapoptotic $\mathrm{Bcl}-2$-homology domain 3 (BH3) [20]. These germline alterations could have a crucial role in determining how a tumor responds to EGFR-TKIs; however, few studies (none from Latin America) have examined the clinical usefulness of detecting BIM deletion polymorphisms and its relation with clinical characteristics in EGFR positive NSCLC. To determine the usefulness of detecting BIM-del in patients with EGFR mutationpositive NSCLC, we examined the outcomes of Hispanic patients with and without BIM alterations.

\section{RESULTS}

\section{Demographic and clinicopathologic characteristics}

The characteristics of the patients included in the study are summarized in Table 1. As expected in EGFR mutated patients, adenocarcinoma histology and non-smokers were both frequent characteristics. EGFR common mutations were present in the majority of patients (84/89 patients) including deletion of exon 19 (46 patients) and L858R (38 patients). BIM-del was present in 14 patients (15.7\%). There were no significant differences between patients with and without BIM-del regarding clinical characteristics or type of EGFR mutation, but a difference was obtained with previous tobacco exposure $(\mathrm{p}=0.04)($ Table 2$)$.

\section{Response to TKI therapy and survival}

There was a significant difference in ORR between patients with and without BIM-del. Patients who were BIMdel + had a worse ORR to erlotinib compared to patients with a BIM del- $(42.9 \%$ vs. $73.3 \%$; $\mathrm{p}=0.024)$ (Table 3$)$. There was no difference in ORR to chemotherapy between BIM-del+ and BIM del-populations (Table 3). Overall survival (OS) was 32.9 months (95\% CI 31.1-34.6) and overall PFS was 19.5 months (95\% CI 9.7-25.4) (Figure 1A and 1B). Patients with BIM-del+ had a significantly shorter PFS (10.8 vs. 21.7 months for those patients without BIM-del; $\mathrm{p}=0.029$ ) (Figure $2 \mathrm{~A})$ and detrimental OS (15.5 vs. 34.0 months for patients without BIM-del; $\mathrm{p}=0.035$ ) (Figure 2B). Multivariate Cox regression analysis showed that BIM-del was an independent indicator of shorter PFS (HR 3.0; 95\% CI 1.2-7.6; $\mathrm{p}=0.01$ ) and OS (HR 3.4; 95\%CI 1.4-8.3; $\mathrm{p}=0.006$ ) (Table 3).

\section{Toxicity}

Thirty-eight (42.6\%) patients suffered grade 3 or 4 adverse event. Most patients experienced rash (36\%), fatigue (30\%), diarrhea (16\%) and anorexia (10\%), but no unexpected serious adverse reactions were reported. Major toxicity was not influenced by BIM-del $(\mathrm{p}=0.68)$. 
Table 1: Patient characteristics according to Bcl-2-Like Protein 11 (BIM) deletion polymorphism

\begin{tabular}{|c|c|c|c|c|}
\hline Variable & $\mathrm{N}=89(\%)$ & $\begin{array}{l}\text { BIM-del+ } \\
\mathrm{N}=14(\%)\end{array}$ & $\begin{array}{c}\text { BIM del- } \\
\mathrm{N}=75(\%)\end{array}$ & P-value \\
\hline \multicolumn{5}{|l|}{ Gender } \\
\hline Female & $62(69.7)$ & $9(64.3)$ & $53(70.7)$ & 0.06 \\
\hline Male & $27(30.3)$ & $5(35.7)$ & $22(29.3)$ & \\
\hline Age, mean & $\begin{array}{c}59.4 \\
(+/-14.3)\end{array}$ & $\begin{array}{c}52.6 \\
(+/-13.7)\end{array}$ & $\begin{array}{c}60.8 \\
(+/-11.8)\end{array}$ & 0.07 \\
\hline$>60$ years & $50(56.2)$ & $5(35.8)$ & $45(60.0)$ & \\
\hline$<60$ years & $39(43.8)$ & $9(64.2)$ & $30(40.0)$ & \\
\hline \multicolumn{5}{|l|}{ ECOG } \\
\hline 0 & $11(12.4)$ & $2(14.3)$ & $9(12.0)$ & 0.54 \\
\hline 1 & $44(49.4)$ & $5(35.7)$ & $39(52.0)$ & \\
\hline 2 & $31(34.8)$ & $7(50.0)$ & $24(32.0)$ & \\
\hline 3 & $3(3.4)$ & - & $3(4.0)$ & \\
\hline ND & - & - & - & \\
\hline \multicolumn{5}{|l|}{ Stage } \\
\hline IIIA & $1(1.1)$ & - & $1(1.3)$ & 0.78 \\
\hline IIIB & $4(4.5)$ & - & $4(5.3)$ & \\
\hline IV & $84(94.4)$ & $14(100.0)$ & $70(93.3)$ & \\
\hline \multicolumn{5}{|l|}{ Histology } \\
\hline Adenocarcinoma & 87 (97.8) & $14(100.0)$ & $73(96.8)$ & 0.63 \\
\hline LCC & $1(1.1)$ & & $1(1.6)$ & \\
\hline $\begin{array}{l}\text { NOS/ } \\
\text { Adenosquamous }\end{array}$ & $1(1.1)$ & & $1(1.6)$ & \\
\hline \multicolumn{5}{|l|}{$\begin{array}{l}\text { Histologic pattern } \\
\text { (adenocarcinoma) }\end{array}$} \\
\hline Lepidic & $9(10.1)$ & $2(14.3)$ & $7(9.3)$ & 0.53 \\
\hline Acinar & $10(11.2)$ & - & $10(13.3)$ & \\
\hline Papillary & $17(19.1)$ & $2(14.3)$ & $15(20.0)$ & \\
\hline Micropapillary & $17(19.1)$ & $3(21.4)$ & 14 (18.7) & \\
\hline Solid & $4(4.5)$ & - & $4(5.3)$ & \\
\hline ND & $32(36.0)$ & $7(50.0)$ & $25(33.3)$ & \\
\hline \multicolumn{5}{|l|}{ Smoking history } \\
\hline Never & $50(56.2)$ & $11(78.6)$ & $39(52.0)$ & 0.04 \\
\hline Former/Current & 37 (41.6) & $3(21.4)$ & $34(45.3)$ & \\
\hline ND & $2(2.2)$ & & $2(2.7)$ & \\
\hline \multicolumn{5}{|l|}{$\begin{array}{l}\text { Pleuro/pulmonary } \\
\text { metastases }\end{array}$} \\
\hline Yes & $44(49.4)$ & $5(35.7)$ & $39(52.0)$ & 0.60 \\
\hline
\end{tabular}




\begin{tabular}{|c|c|c|c|c|}
\hline Variable & $\mathrm{N}=89(\%)$ & $\begin{array}{l}\text { BIM-del+ } \\
\mathrm{N}=14(\%)\end{array}$ & $\begin{array}{c}\text { BIM del- } \\
\text { N=75 (\%) }\end{array}$ & P-value \\
\hline No & $40(44.9)$ & $9(64.3)$ & $31(41.3)$ & \\
\hline ND & $5(5.6)$ & - & $5(6.7)$ & \\
\hline \multicolumn{5}{|c|}{ CNS metastases } \\
\hline Yes & $34(38.2)$ & $6(42.9)$ & $28(37.3)$ & 0.58 \\
\hline No & $48(53.9)$ & $8(57.1)$ & $40(53.3)$ & \\
\hline ND & $7(7.9)$ & - & $7(9.3)$ & \\
\hline \multicolumn{5}{|c|}{ Liver metastases } \\
\hline Yes & $33(37.1)$ & $7(50.0)$ & $26(34.7)$ & 0.72 \\
\hline No & $50(56.2)$ & $7(50.0)$ & $43(57.3)$ & \\
\hline ND & $6(6.7)$ & - & $6(8.0)$ & \\
\hline \multicolumn{5}{|c|}{ Bone metastases } \\
\hline Yes & $39(43.8)$ & $6(42.9)$ & $33(44.0)$ & 0.65 \\
\hline No & $48(53.9)$ & $8(57.1)$ & $40(53.3)$ & \\
\hline ND & $2(2.2)$ & - & $2(2.7)$ & \\
\hline \multicolumn{5}{|c|}{ Lymph node metastases } \\
\hline Yes & $43(48.4)$ & $10(71.4)$ & $33(44.0)$ & 0.60 \\
\hline No & $46(51.6)$ & $4(28,6)$ & $42(56.0)$ & \\
\hline \multicolumn{5}{|c|}{ Weight loss } \\
\hline Yes & $45(50.6)$ & $7(50.0)$ & $38(50.7)$ & 0.78 \\
\hline No & $40(44.9)$ & $6(42.9)$ & $34(45.3)$ & \\
\hline ND & $4(4.5)$ & $1(7.1)$ & $3(4.0)$ & \\
\hline
\end{tabular}

LCC: Large Cell Carcinoma; NOS: Not Otherwise Specified

Table 2: EGFR and BIM distribution

\begin{tabular}{lc}
\hline Variable & N=89 (\%) \\
\hline Type of EGFR mutation & $84(94.4)$ \\
Common & $5(5.6)$ \\
Uncommon & \\
EGFR subgroup & $46(50.7)$ \\
Del19 (12 pb) & $38(42.6)$ \\
L858R & $5(6.7)$ \\
G719X & \\
BIM global & $14(15.7)$ \\
Positive & $75(84.3)$ \\
Negative & \\
BCL2-like 11 par $\mathbf{4 2 2 6}$ bp & $78(87.6)$ \\
Negative & $11(12.4)$ \\
Positive & \\
BCL2-like 11 par $\mathbf{3 6 3}$ bp & $79(88.8)$ \\
Negative & $10(11.2)$ \\
Positive &
\end{tabular}

\section{DISCUSSION}

Several studies have demonstrated that BIM deletion polymorphism is related with response to EGFR TKIs in NSCLC [20, 24-28]. BIM deletion polymorphism is an independent predictive factor of response to EGRF TKIs. Patients with a BIM del+ have low response rate to EGFR TKIs and have inferior clinical outcomes (PFS and or OS) compared to patients without BIM deletion [20, 25, 27]. BIM deletion polymorphism is relatively common in East Asians, but unusual in the European and African populations [20]. Our study documented for the first time the prevalence of BIM deletion polymorphism in the Latin American population ( $15.7 \%$; 14 of 89 patients). This prevalence is similar to that previously reported in the Asian population [24-26, 28]. We did not analyze the prevalence of BIM deletion polymorphism in healthy volunteers. In this study we also found that BIM deletion polymorphism was not related with any clinical or pathological factor and its prevalence is independent of the type of EGFR activating mutation.

$\mathrm{Ng}$ et al. showed that BIM deletion polymorphisms are associated with inferior clinical outcomes in patients with NSCLC who received EGFR TKIs therapy [20]. In Ng 
el al, study patients with BIM del+ had a shorter PFS (6.6 moths) compared with BIM del- patients (11.9 months) (n $=141, \mathrm{p}=0.0027)$. Other studies from the Asian population have shown similar results demonstrating that the presence of BIM deletion polymorphism is a negative predictive factor of response rate, PFS and OS to EGFR TKIs [24, $25,27]$. In a meta-analysis of six original eligible studies including 871 NSCLC patients [29], patients BIM del+

Table 3: Response rate in EGFR+ according to BIM-del status

\begin{tabular}{llcc}
\hline Response rate & $\begin{array}{c}\text { BIM-del+ } \\
\text { N=14 (\%) }\end{array}$ & $\begin{array}{c}\text { BIM del- } \\
\text { N=75 (\%) }\end{array}$ & P \\
\hline Response to TKIs & & & \\
Yes & $5(35.7)$ & $55(73.3)$ & 0.002 \\
No & $9(64.3)$ & $20(26.7)$ & \\
Response to chemotherapy & & & \\
Yes & $4(28.6)$ & $24(32.0)$ & \\
No & $5(35.7)$ & $23(30.7)$ & \\
ND & $5(35.7)$ & $28(37.3)$ & \\
\hline
\end{tabular}

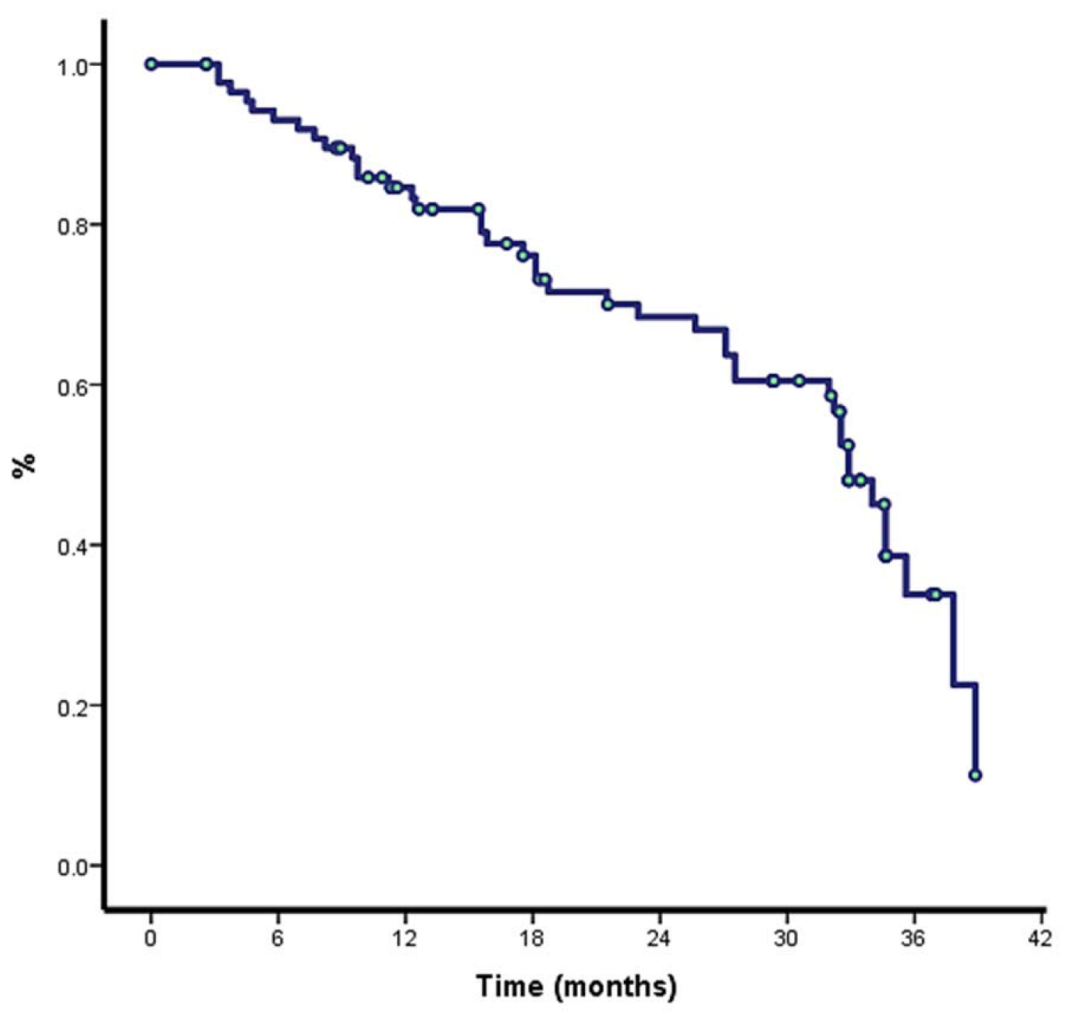

\begin{tabular}{|l|l|l|l|l|l|l|l|}
\hline \multirow{4}{*}{ Number at risk } & \multicolumn{7}{|c|}{ Months } \\
\cline { 2 - 9 } & $\mathbf{6}$ & $\mathbf{1 2}$ & $\mathbf{1 8}$ & $\mathbf{2 4}$ & $\mathbf{3 0}$ & $\mathbf{3 6}$ & $\mathbf{4 2}$ \\
\cline { 2 - 9 } & 82 & 76 & 70 & 65 & 60 & 50 & 48 \\
\hline Events & 7 & 13 & 19 & 24 & 29 & 39 & 41 \\
\hline
\end{tabular}

Figure 1: A. Kaplan-Meier curve for overall survival (OS) after epidermal growth factor receptor (EGFR)-tyrosine kinase inhibitor treatment. 


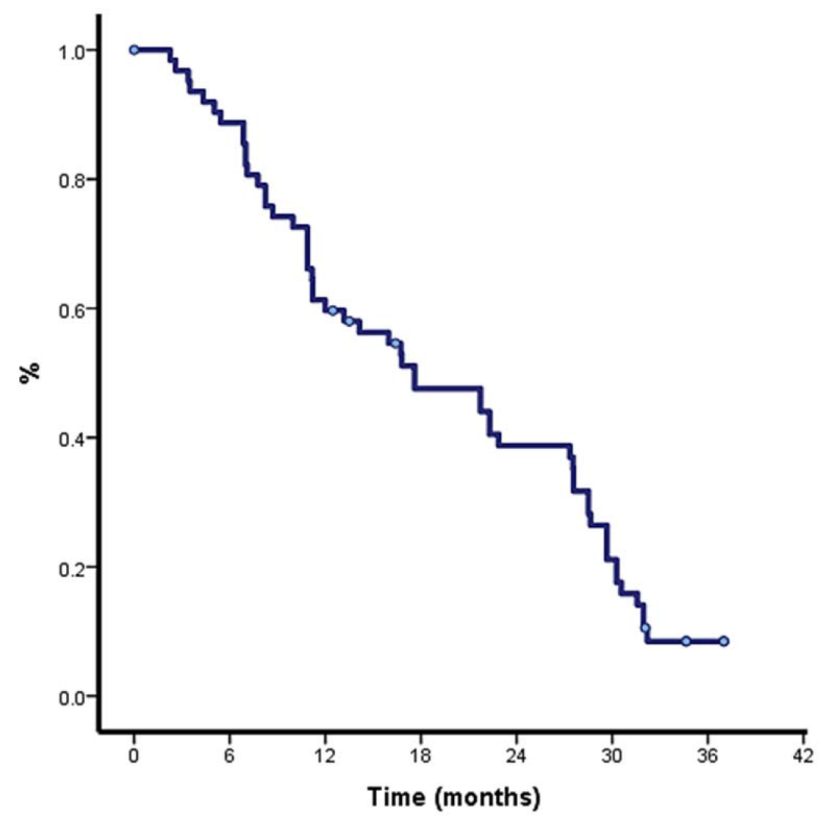

\begin{tabular}{|l|l|l|l|l|l|l|l|}
\hline \multirow{4}{*}{ Number at risk } & \multicolumn{7}{|c|}{ Months } \\
\cline { 2 - 9 } & $\mathbf{6}$ & $\mathbf{1 2}$ & $\mathbf{1 8}$ & $\mathbf{2 4}$ & $\mathbf{3 0}$ & $\mathbf{3 6}$ & $\mathbf{4 2}$ \\
\cline { 2 - 9 } & 82 & 64 & 57 & 49 & 39 & 29 & 27 \\
\hline Events & 7 & 18 & 7 & 5 & 10 & 7 & 0 \\
\hline
\end{tabular}

Figure 1: B. Progression free survival.

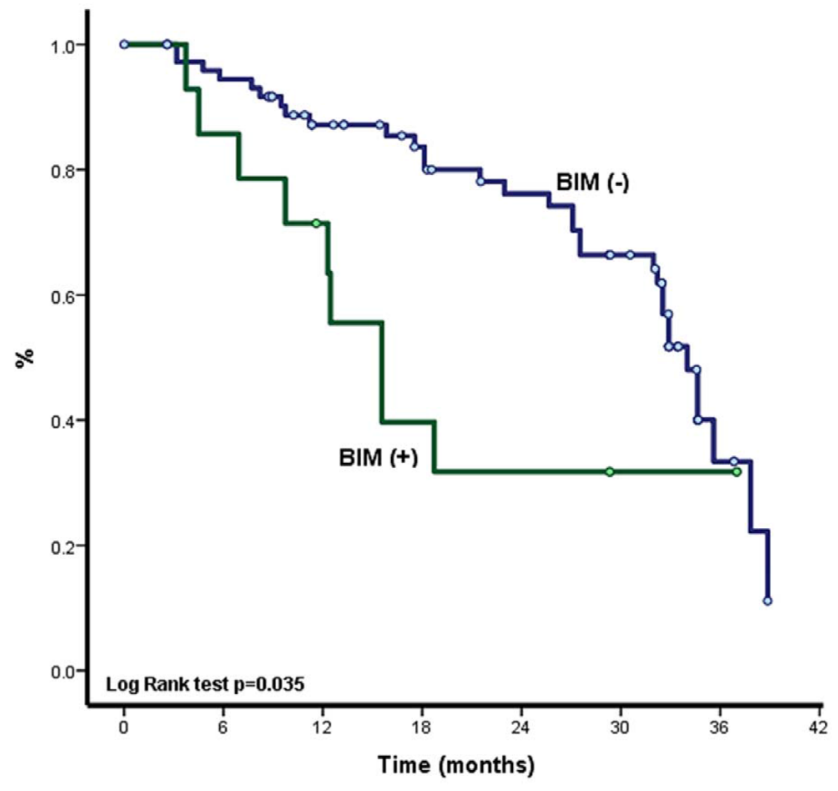

\begin{tabular}{|c|l|l|l|l|l|l|l|l|}
\hline \multirow{4}{*}{$\begin{array}{c}\text { BIM polymorphysms } \\
\text { status }\end{array}$} & \multicolumn{6}{|c|}{ Months } \\
\cline { 2 - 10 } & $\mathbf{6}$ & $\mathbf{1 2}$ & $\mathbf{1 8}$ & $\mathbf{2 4}$ & $\mathbf{3 0}$ & $\mathbf{3 6}$ & $\mathbf{4 2}$ \\
\cline { 2 - 10 } & NIM-del (-) & 68 & 63 & 61 & 57 & 52 & 45 & 43 \\
\cline { 2 - 9 } & BIM-del (+) & 12 & 9 & 5 & 4 & 2 & 2 & 0 \\
\hline
\end{tabular}

Figure 2: A. Overall survival in EGFR+ according to BIM status. 


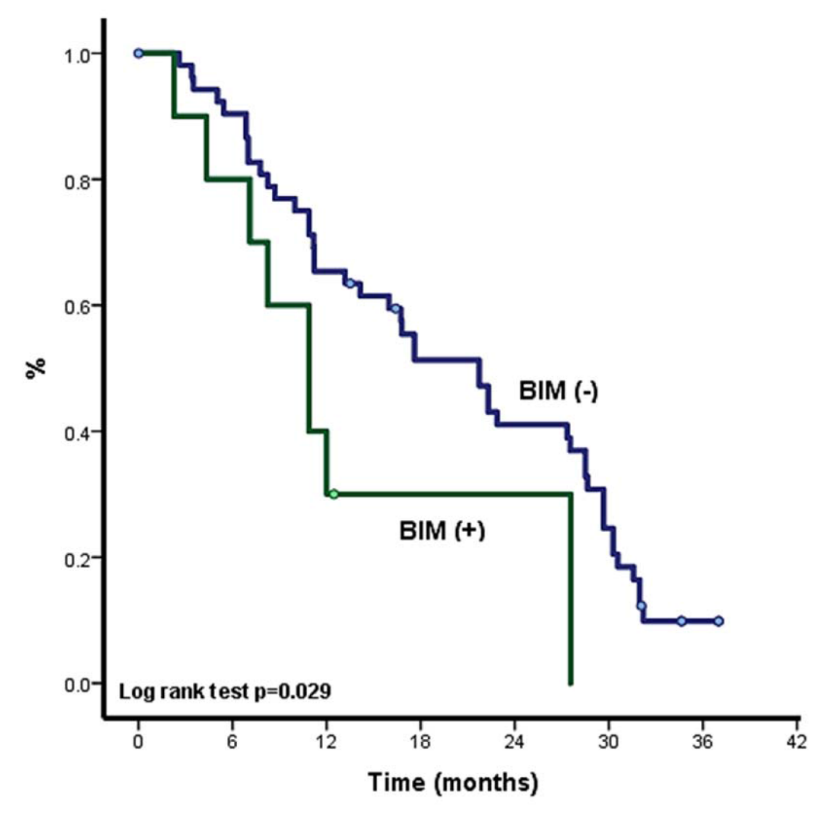

\begin{tabular}{|c|c|c|c|c|c|c|c|c|}
\hline & \multirow{2}{*}{$\begin{array}{c}\text { BIM polymorphysms } \\
\text { status }\end{array}$} & \multicolumn{7}{|c|}{ Months } \\
\hline \multirow{3}{*}{ Number at risk } & & 6 & 12 & 18 & 24 & 30 & 36 & 42 \\
\hline & BIM-del (-) & 70 & 57 & 48 & 43 & 35 & 25 & 23 \\
\hline & BIM-del (+) & 12 & 7 & 6 & 6 & 4 & 4 & 4 \\
\hline
\end{tabular}

Figure 2: B. Progression free survival in EGFR+ according to BIM-del status.

had poor response to EGFR TKI therapy $(\mathrm{p}=0.001, \mathrm{OR}=$ $0.39 ; 95 \% \mathrm{CI}=0.23-0.67)$. Disease control rate $(\mathrm{DCR})$ with EGFR TKI treatment was significantly decreased in BIM del + patients $(p=0.007, O R=0.46,95 \% \mathrm{CI}=0.25-0.85)$. Also, PFS and OS were significantly shorter in NSCLC EGFR-mutated patients with BIM deletion polymorphism (PFS: $\mathrm{p}<0.001, \mathrm{HR}=1.37,95 \% \mathrm{CI}=1.09-1.71$; OS: $\mathrm{p}=$ $0.003, \mathrm{HR}=1.25,95 \% \mathrm{CI}=1.08-1.45$ ). Our results are consistent with these studies, suggesting that NSCLC EGFR mutation positive patients with BIM deletion polymorphism benefit less from EGFR TKI therapy in terms of PFS and OS compared to patients without BIM deletion polymorphism. BIM deletion polymorphism was an independent indicator of shorter PFS and OS in our population.

In the literature there are other studies with contradictory results to our study, failing to demonstrate an association between BIM deletion polymorphism and the response to EGFR TKI therapy [26, 28]. For example, Lee et al analyzed the influence of BIM deletion polymorphism in 205 NSCLC EGFR mutation positive patients [28]. BIM del+ patients had similar objective response rates compared to BIM del- patients (91\% vs. $84 \%, \mathrm{p}=0.585)$. PFS and OS did not differ significantly between both molecular selected populations (PFS $=12$ vs. 11 months, $\mathrm{p}=0.160 ; \mathrm{OS}=31$ vs. 30 months, $\mathrm{p}=0.452)$. Similar results were reported in another study performed in the Asian population [26]. Different hypothesis have been proposed to explain these contradictory results. For instance, the response to EGFR TKIs varies according to the level of the proapoptotic Bcl2-homology domain 3 (BH3). Such changes in BH3 and not only the presence of BIM polymorphism itself could therefore explain these diverging results [30]. Likewise, there may be additional ethnic differences in BIM polymorphisms between East Asian and Latin American. Therefore measuring BIM mRNA levels before treatment should be encouraged to establish the role of BIM as a predictor of response to EGFR TKI therapy [30, 31].

Other pro-apoptic proteins belonging to $\mathrm{BCL}-2$ family such a BAX, BAK, PUMA and BAD might also play an important role in the response in oncogeneaddicted cancer and activation of apoptosis in NSCLC [32-35]. Variations of the expression of these BCL2 family proteins could influence the response to TKI therapy in the studies where BIM polymorphisms were evaluated. Further examination of additional genes such as TP53, PTEN and PIK3CA mutations might be useful to unveil the variety of responses to EGFR TKIs [34, 36, 37].

The present study had several limitations including sample size and bias related to the retrospective nature of data collection. We did not analyze BIM deletion polymorphism in blood samples, however there seems to be a concordance between peripheral venous blood and FFPE [25]; still, the validation of BIM deletion polymorphisms in blood samples is warranted as a non- 
invasive method that allows tissue sparing. Also, we did not validate other genetic alterations such a BCL-2 family proteins distinct to BIM, PTEN, PI3K, etc., in order to explain different responses to EGFR TKIs.

\section{MATERIALS AND METHODS}

\section{Patients and samples}

This is a retrospective study following the results described by $\mathrm{Ng}$ and colleagues [20]. We included 89 patients carriers of EGFR mutations evaluated at the Clinical and Applied Cancer Research Foundation in Bogotá, Colombia. Samples and information were collected from January 1, 2011 to March 31, 2014. All patients met the following inclusion criteria: informed consent; histological confirmed non-squamous NSCLC, locally advanced or advanced disease (stage IV), no previous systemic treatment, age $>18$ years; and adequate formalin-fixed, paraffin-embedded (FFPE) tissue available to detect EGFR mutations and their BIM polymorphism status. We also obtained a complete medical history, laboratory tests results, and radiology examinations for each patient. All cases were treated with erlotinib $150 \mathrm{mg}$ daily until disease progression or intolerable toxicity.

\section{DNA extraction and EGFR mutation detection}

DNA from tumor tissue was extracted using the DNeasy Tissue Kit or the QIAamp DNA FFPE Tissue Kit (Qiagen, Hilden, Germany) according to the manufacturer's protocol. EGFR mutations were studied by COBAS 8100 (Cobas real-time PCR platform, Roche Diagnostics, Indianapolis, Indiana, US).

\section{BIM genotyping and direct sequencing}

All samples were amplified by polymerase chain reaction (PCR) to detect $B I M$ polymorphisms using the following primer sequences: wild-type (WT) BIM forward primer, 50-ACTGTAAAACGACGGCCAGTCCTCATGA TGAAGGCTAACTCAA-30; and reverse primer, 50-ACC AGGAAACAGCTATGACCAACCTCTGACAAGTG ACCACCA-30. For the BIM deletion polymorphism, the forward primer sequence was the same as that used for wild type BIM, and the reverse sequence was 50-ACCAGGAAA CAGCTATGACCGGCACAGCCTCTATGGAGAACA-30. The reaction condition was $95^{\circ} \mathrm{C}$ for 10 minutes followed by 40 cycles at $94^{\circ} \mathrm{C}$ for 30 seconds, $60^{\circ} \mathrm{C}$ for 30 seconds, and $72^{\circ} \mathrm{C}$ for 30 seconds; and a final extension at $72^{\circ} \mathrm{C}$ for 10 minutes using the Taq Polymerase premix PCR Kit (Applied Biosystems). PCR products (177 base pairs [bp] for the BIM deletion polymorphism and $174 \mathrm{bp}$ for wild-type BIM were then separated on a 3\% agarose gel with nucleic acid dye by electrophoresis and were purified before direct sequencing.
To check the presence of somatic mutations in the BCL2L11 gene, a comprehensive screening was performed by direct sequencing including rare mutations described in COSMIC (0.2\%; p.Q37Q, p.G49R, p.R85I, p.F97L, p.R188L, p.W195C) without finding any.

\section{Statistical analysis}

Statistical analyses were conducted using SPSS software 19.0 (SPSS, Chicago, IL, U.S.A.). Differences in clinical characteristics, overall response rate (ORR), PFS, OS and adverse events of patients with or without BIM deletion polymorphism (BIM-del+; BIM del-) were compared using the Pearson chisquare test or the Fisher's exact test. Survival curves were drawn by the KaplanMeier method, and statistical analysis was performed using the log-rank test. We used univariate analysis and multivariate Cox regression analysis (including type of EGFR mutation, BIM-del, response to TKIs, ECOG and brain metastases) to identify factors associated with PFS and OS. We studied the following clinical characteristics: age, sex, performance status, stage, weight loss, site of metastasis (brain, bone, lung, liver, lymph nodes), type of EGFR mutation [common mutations (L858R and exon 19 deletion) vs. uncommon mutations], EGFRTKI response, chemotherapy response, smoking history, and BIM-del. For any purpose ORR was defined as the proportion of patients with tumor size reduction during TKI treatment, PFS was defined as the length of time between starting TKI and disease progression or death, and OS is the period of time from date of diagnosis until death.

\section{CONCLUSIONS}

The BIM deletion polymorphism is present in this Hispanic NSCLC EGFR mutated cohort of patients with a similar incidence to Asian countries. In our population, the presence of the BIM deletion polymorphism was an important and independent predictive factor of response when patients were treated with an EGFR TKI therapy.

\section{ACKNOWLEDGMENTS}

The authors are grateful for the generous contribution from the Silberman family and José María Buendía for altruistically promoting the development of cancer research in Colombia.

\section{CONFLICTS OF INTEREST}

The authors declare no conflicts of interest.

Preliminary results from this study have previously been shared during the 2014 LALCA Meeting. 


\section{FUNDING}

Supported by Foundation for Clinical and Applied Cancer Research- FICMAC (Bogotá, Colombia) research grant 019-2014.

\section{Author contributions}

Conceived and designed the study and experiments: AFC, LR, OA, NR, RR.

Contributed reagents/materials/analysis tools: HC, $\mathrm{CV}$, JO, JR, PA.

Wrote the paper: AFC, LR, BW, MC, LC-R, CM, $\mathrm{CO}, \mathrm{SF}, \mathrm{CR}, \mathrm{NR}, \mathrm{RR}$.

\section{REFERENCES}

1. Goldstraw P, Ball D, Jett JR, Le Chevalier T, Lim E, Nicholson AG, Shepherd FA. Non-small-cell lung cancer. Lancet. 2011; 378:1727-40. doi: 10.1016/S0140-6736(10)62101-0.

2. (IARC) IAfRoC. GLOBOCAN 2012: Estimated Cancer Incidence, Mortality and Prevalence Worldwide in 2012. Retrieved 08/06/2015. 2012.

3. Lynch TJ, Bell DW, Sordella R, Gurubhagavatula S, Okimoto RA, Brannigan BW, Harris PL, Haserlat SM, Supko JG, Haluska FG, Louis DN, Christiani DC, Settleman $\mathrm{J}$, Haber DA. Activating mutations in the epidermal growth factor receptor underlying responsiveness of non-small-cell lung cancer to gefitinib. N Engl J Med. 2004; 350:2129-39. doi: 10.1056/NEJMoa040938.

4. Shigematsu H, Lin L, Takahashi T, Nomura M, Suzuki M, Wistuba II, Fong KM, Lee H, Toyooka S, Shimizu N, Fujisawa T, Feng Z, Roth JA, et al. Clinical and biological features associated with epidermal growth factor receptor gene mutations in lung cancers. J Natl Cancer Inst. 2005; 97:339-46. doi: 10.1093/jnci/dji055.

5. Bell DW, Lynch TJ, Haserlat SM, Harris PL, Okimoto RA, Brannigan BW, Sgroi DC, Muir B, Riemenschneider MJ, Iacona RB, Krebs AD, Johnson DH, Giaccone G, et al. Epidermal growth factor receptor mutations and gene amplification in non-small-cell lung cancer: molecular analysis of the IDEAL/INTACT gefitinib trials. J Clin Oncol. 2005; 23:8081-92. doi: 10.1200/JCO.2005.02.7078.

6. Arrieta O, Cardona AF, Martín C, Más-López L, CorralesRodríguez L, Bramuglia G, Castillo-Fernandez O, Meyerson M, Amieva-Rivera E, Campos-Parra AD, Carranza H, Gómez de la Torre JC, Powazniak Y, et al. Updated frequency of EGFR and KRAS mutations in nonsmall-cell lung cancer in Latin America: The Latin-American Consortium for the Investigation of lung Cancer (CLICaP). J Thorac Oncol. 2015; 10:838-43. doi: 10.1097/JTO.0000000000000481.

7. Mok TS, Wu YL, Thongprasert S, Yang CH, Chu DT, Saijo $\mathrm{N}$, Sunpaweravong P, Han B, Margono B, Ichinose Y, Nishiwaki Y, Ohe Y, Yang JJ, et al. Gefitinib or carboplatinpaclitaxel in pulmonary adenocarcinoma. N Engl J Med. 2009; 361:947-57. doi: 10.1056/NEJMoa0810699.
8. Maemondo M, Inoue A, Kobayashi K, Sugawara S, Oizumi S, Isobe H, Gemma A, Harada M, Yoshizawa H, Kinoshita I, Fujita Y, Okinaga S, Hirano H, et al, and North-East Japan Study Group. Gefitinib or chemotherapy for non-small-cell lung cancer with mutated EGFR. N Engl J Med. 2010; 362:2380-88. doi: 10.1056/NEJMoa0909530.

9. Zhou C, Wu YL, Chen G, Feng J, Liu XQ, Wang C, Zhang S, Wang J, Zhou S, Ren S, Lu S, Zhang L, Hu C, et al. Erlotinib versus chemotherapy as first-line treatment for patients with advanced EGFR mutation-positive non-smallcell lung cancer (OPTIMAL, CTONG-0802): a multicentre, open-label, randomised, phase 3 study. Lancet Oncol. 2011; 12:735-42. doi: 10.1016/S1470-2045(11)70184-X.

10. Sequist LV, Yang JC, Yamamoto N, O’Byrne K, Hirsh V, Mok T, Geater SL, Orlov S, Tsai CM, Boyer M, Su WC, Bennouna J, Kato T, et al. Phase III study of afatinib or cisplatin plus pemetrexed in patients with metastatic lung adenocarcinoma with EGFR mutations. J Clin Oncol. 2013; 31:3327-34. doi: 10.1200/JCO.2012.44.2806.

11. Ohashi K, Maruvka YE, Michor F, Pao W. Epidermal growth factor receptor tyrosine kinase inhibitor-resistant disease. J Clin Oncol. 2013; 31:1070-80. doi: 10.1200/ JCO.2012.43.3912.

12. Kobayashi S, Boggon TJ, Dayaram T, Jänne PA, Kocher O, Meyerson M, Johnson BE, Eck MJ, Tenen DG, Halmos B. EGFR mutation and resistance of non-small-cell lung cancer to gefitinib. N Engl J Med. 2005; 352:786-92. doi: 10.1056/NEJMoa044238.

13. Pao W, Miller VA, Politi KA, Riely GJ, Somwar R, Zakowski MF, Kris MG, Varmus H. Acquired resistance of lung adenocarcinomas to gefitinib or erlotinib is associated with a second mutation in the EGFR kinase domain. PLoS Med. 2005; 2:e73. doi: 10.1371/journal.pmed.0020073.

14. Engelman JA, Zejnullahu K, Mitsudomi T, Song Y, Hyland C, Park JO, Lindeman N, Gale CM, Zhao X, Christensen J, Kosaka T, Holmes AJ, Rogers AM, et al. MET amplification leads to gefitinib resistance in lung cancer by activating ERBB3 signaling. Science. 2007; 316:1039-43. doi: 10.1126/science.1141478.

15. Sequist LV, Waltman BA, Dias-Santagata D, Digumarthy S, Turke AB, Fidias P, Bergethon K, Shaw AT, Gettinger S, Cosper AK, Akhavanfard S, Heist RS, Temel J, et al. Genotypic and histological evolution of lung cancers acquiring resistance to EGFR inhibitors. Sci Transl Med. 2011; 3:75ra26. doi: 10.1126/scitranslmed.3002003.

16. Takeda M, Okamoto I, Fujita Y, Arao T, Ito H, Fukuoka M, Nishio K, Nakagawa K. De novo resistance to epidermal growth factor receptor-tyrosine kinase inhibitors in EGFR mutation-positive patients with non-small cell lung cancer. J Thorac Oncol. 2010; 5:399-400. doi: 10.1097/ JTO.0b013e3181cee47e.

17. Cappuzzo F, Jänne PA, Skokan M, Finocchiaro G, Rossi E, Ligorio C, Zucali PA, Terracciano L, Toschi L, Roncalli M, Destro A, Incarbone M, Alloisio M, et al. MET increased gene copy number and primary resistance to gefitinib 
therapy in non-small-cell lung cancer patients. Ann Oncol. 2009; 20:298-304. doi: 10.1093/annonc/mdn635.

18. Tanaka A, Sueoka-Aragane N, Nakamura T, Takeda Y, Mitsuoka M, Yamasaki F, Hayashi S, Sueoka E, Kimura S. Co-existence of positive MET FISH status with EGFR mutations signifies poor prognosis in lung adenocarcinoma patients. Lung Cancer. 2012; 75:89-94. doi: 10.1016/j.lungcan.2011.06.004.

19. Sos ML, Koker M, Weir BA, Heynck S, Rabinovsky R, Zander T, Seeger JM, Weiss J, Fischer F, Frommolt P, Michel K, Peifer M, Mermel C, et al. PTEN loss contributes to erlotinib resistance in EGFR-mutant lung cancer by activation of Akt and EGFR. Cancer Res. 2009; 69:325661. doi: 10.1158/0008-5472.CAN-08-4055.

20. Ng KP, Hillmer AM, Chuah CT, Juan WC, Ko TK, Teo AS, Ariyaratne PN, Takahashi N, Sawada K, Fei Y, Soh $\mathrm{S}$, Lee WH, Huang JW, et al. A common BIM deletion polymorphism mediates intrinsic resistance and inferior responses to tyrosine kinase inhibitors in cancer. Nat Med. 2012; 18:521-28. doi: 10.1038/nm.2713.

21. Youle RJ, Strasser A. The BCL-2 protein family: opposing activities that mediate cell death. Nat Rev Mol Cell Biol. 2008; 9:47-59. doi: 10.1038/nrm2308.

22. Faber AC, Ebi H, Costa C, Engelman JA. Apoptosis in targeted therapy responses: the role of BIM. Adv Pharmacol. 2012; 65:519-42. doi: 10.1016/B978-0-12-397927-8.00016-6.

23. Costa DB, Halmos B, Kumar A, Schumer ST, Huberman MS, Boggon TJ, Tenen DG, Kobayashi S. BIM mediates EGFR tyrosine kinase inhibitor-induced apoptosis in lung cancers with oncogenic EGFR mutations. PLoS Med. 2007; 4:1669-79. doi: 10.1371/journal.pmed.0040315.

24. Isobe $\mathrm{K}$, Hata $\mathrm{Y}$, Tochigi N, Kaburaki K, Kobayashi H, Makino T, Otsuka H, Sato F, Ishida F, Kikuchi N, Hirota N, Sato K, Sano G, et al. Clinical significance of BIM deletion polymorphism in non-small-cell lung cancer with epidermal growth factor receptor mutation. J Thorac Oncol. 2014; 9:483-87. doi: 10.1097/JTO.0000000000000125.

25. Lee JH, Lin YL, Hsu WH, Chen HY, Chang YC, Yu CJ, Shih JY, Lin CC, Chen KY, Ho CC, Laio WY, Yang PC, Yang JC. Bcl-2-like protein 11 deletion polymorphism predicts survival in advanced non-small-cell lung cancer. J Thorac Oncol. 2014; 9:1385-92. doi: 10.1097/JTO.0000000000000238.

26. Lee JK, Shin JY, Kim S, Lee S, Park C, Kim JY, Koh Y, Keam B, Min HS, Kim TM, Jeon YK, Kim DW, Chung DH, et al. Primary resistance to epidermal growth factor receptor (EGFR) tyrosine kinase inhibitors (TKIs) in patients with non-small-cell lung cancer harboring TKI-sensitive EGFR mutations: an exploratory study. Ann Oncol. 2013; 24:2080-87. doi: 10.1093/annonc/mdt127.

27. Zhao M, Zhang Y, Cai W, Li J, Zhou F, Cheng N, Ren R, Zhao C, LiX, RenS, Zhou C, HirschFR. TheBim deletion polymorphism clinical profile and its relation with tyrosine kinase inhibitor resistance in Chinese patients with non-small cell lung cancer. Cancer. 2014; 120:2299-307. doi: 10.1002/cncr.28725.

28. Lee JY, Ku BM, Lim SH, Lee MY, Kim H, Kim M, Kim S, Jung HA, Sun JM, Ahn JS, Park K, Ahn MJ. The BIM
Deletion Polymorphism and its Clinical Implication in Patients with EGFR-Mutant Non-Small-Cell Lung Cancer Treated with EGFR Tyrosine Kinase Inhibitors. J Thorac Oncol. 2015; 10:903-09. doi: 10.1097/JTO.0000000000000535.

29. Ma JY, Yan HJ, Gu W. Association between BIM deletion polymorphism and clinical outcome of EGFR-mutated NSCLC patient with EGFR-TKI therapy: A meta-analysis. J Cancer Res Ther. 2015; 11:397-402. doi: 10.4103/2152-7806.157308.

30. Faber AC, Corcoran RB, Ebi H, Sequist LV, Waltman BA, Chung E, Incio J, Digumarthy SR, Pollack SF, Song Y, Muzikansky A, Lifshits E, Roberge S, et al. BIM expression in treatment-naive cancers predicts responsiveness to kinase inhibitors. Cancer Discov. 2011; 1:352-65. doi: 10.1158/2159-8290.CD-11-0106.

31. Costa C, Molina MA, Drozdowskyj A, Giménez-Capitán A, Bertran-Alamillo J, Karachaliou N, Gervais R, Massuti B, Wei J, Moran T, Majem M, Felip E, Carcereny E, et al. The impact of EGFR T790M mutations and BIM mRNA expression on outcome in patients with EGFR-mutant NSCLC treated with erlotinib or chemotherapy in the randomized phase III EURTAC trial. Clin Cancer Res. 2014; 20:2001-10. doi: 10.1158/1078-0432.CCR-13-2233.

32. Wei MC, Zong WX, Cheng EH, Lindsten T, Panoutsakopoulou V, Ross AJ, Roth KA, MacGregor GR, Thompson CB, Korsmeyer SJ. Proapoptotic BAX and BAK: a requisite gateway to mitochondrial dysfunction and death. Science. 2001; 292:727-30. doi: 10.1126/science.1059108.

33. Groeger AM, Esposito V, De Luca A, Cassandro R, Tonini G, Ambrogi V, Baldi F, Goldfarb R, Mineo TC, Baldi A, Wolner E. Prognostic value of immunohistochemical expression of $\mathrm{p} 53$, bax, $\mathrm{Bcl}-2$ and $\mathrm{Bcl}-\mathrm{xL}$ in resected nonsmall-cell lung cancers. Histopathology. 2004; 44:54-63. doi: 10.1111/j.1365-2559.2004.01750.x.

34. Shabnam MS, Srinivasan R, Wali A, Majumdar S, Joshi $\mathrm{K}$, Behera D. Expression of p53 protein and the apoptotic regulatory molecules Bcl-2, Bcl-XL, and Bax in locally advanced squamous cell carcinoma of the lung. Lung Cancer. 2004; 45:181-88. doi: 10.1016/j.lungcan.2004.01.021.

35. Berrieman HK, Smith L, O'Kane SL, Campbell A, Lind MJ, Cawkwell L. The expression of Bcl-2 family proteins differs between nonsmall cell lung carcinoma subtypes. Cancer. 2005; 103:1415-19. doi: 10.1002/cncr.20907.

36. Engelman JA, Mukohara T, Zejnullahu K, Lifshits E, Borrás AM, Gale CM, Naumov GN, Yeap BY, Jarrell E, Sun J, Tracy S, Zhao X, Heymach JV, et al. Allelic dilution obscures detection of a biologically significant resistance mutation in EGFR-amplified lung cancer. J Clin Invest. 2006; 116:2695-706. doi: 10.1172/JCI28656.

37. Yamamoto C, Basaki Y, Kawahara A, Nakashima K, Kage M, Izumi H, Kohno K, Uramoto H, Yasumoto K, Kuwano M, Ono M. Loss of PTEN expression by blocking nuclear translocation of EGR1 in gefitinib-resistant lung cancer cells harboring epidermal growth factor receptoractivating mutations. Cancer Res. 2010; 70:8715-25. doi: 10.1158/0008-5472.CAN-10-0043. 